\title{
OBITUARY.
}

\section{Sir Aubrey Strahan, K.B.E., Sc.D., F.R.S.}

By the death of Sir Aubrey Strahan we lose another of our leading geologists, one who devoted his life to the promotion of our science. He was educated at Eton and St. John's College, Cambridge, and graduated in the Natural Science Tripos in 1874. Shortly afterwards he joined H.M. Geological Survey, on which he remained till his retirement in 1920 .

Most of his geological work was done in conrection with that service. He devoted himself wholeheartedly to the work and was equally successful on the scientific and administrative sides. As a geological surveyor he was ideal : never influenced by hypothetical considerations, his maps were absolutely trustworthy. Equally valuable were his contributions to the Survey Memoirs. A vast amount of labour was devoted to these, whether recording his own work or editing that of others.

The greater part of his survey work dealt with areas in the north of England and in North and South Wales. This work was officially recognized in 1913, when on the retirement of Sir Jethro Teall he was appointed Director of the Survey. His work in the South Wales coalfield naturally turned his attention to economic matters in connection with coal, and as a member of the Royal Commission on Coal Supplies of 1905 he contributed much valuable material embodied in its Report. He devoted great attention to the distribution of concealed Coal-measures below the newer rocks of Great Britain, and published much on the matter, including his Presidential Addresses to Section C of the British Association in 1904 and to the Geological Society of London in 1913. He also conducted an important research into the present rate of denudation in certain English rivers, the results of which were published in various volumes of the Geographical Journal in the years 1908-11.

Perhaps Sir Aubrey's most striking characteristic was his wellbalanced judgment. He had no axe to grind, and everything he wrote was put forward with conciseness, accuracy, and impartiality. He received many honours, being elected a Fellow of the Royal Society in 1903, was President of the Geological Society in 1912-14, was awarded the Wollaston Medal in 1919, and partly in recognition of his valuable services during the war in connection with the preparation and publication of the Special Reports on the Mineral Resources of Great Britain he received the K.B.E. 